\title{
SIFAT ORGANOLEPTIK DAGING BROILER DENGAN LAMA PERENDAMAN BERBEDA DALAM PERASAN LEMON CUI (Citrus microcarpa)
}

Mergy Angelia Sumual, R. Hadju, M. D. Rotinsulu, S. E. Sakul

Fakultas Peternakan Universitas Sam Ratulangi Manado 95115

E - mail : Mergysumual@gmail.com

\begin{abstract}
ABSTRAK
Tujuan penelitian ini ialah untuk mengetahui sifat organoleptik daging broiler yang direndam dalam lemon cui (Citrus microcarpa). Terdapat empat tingkat perlakuan lama perendaman $(4,3$, 2 dan 1 jam) dengan diamati secara organoleptik oleh 50 orang panelis. Dari hasil penelitian ini diketahui lama perendaman memberi penilaian organoleptik pada kisaran warna 4.00 4.82, aroma 4.34 - 5.12, tekstur 4.02 4.52, keempukan 5.20 - 5.36, citarasa 3.98 - 4.58. Berdasarkan hasil penilaian disimpulkan bahwa daging broiler yang direndam selama 1 jam dalam perasan lemon cui secara organoleptik (warna, aroma, tekstur, keempukan dan citarasa) dapat diterima oleh konsumen.
\end{abstract}

Kata kunci: Daging broiler, lemon cui, sifat organoleptik

\section{ABSTRACT}

\section{ORGANOLEPTIC PROPERTIES} OF BROILER MEAT WITH DIFFERENT IMMERSION TIME IN LEMON CUI (Citrus microcarpa).The purpose of this study was to determine the organoleptic properties of broiler meat marinated in lemon cui (Citrus microcarpa). There are four levels of immersion duration of treatment $(4,3,2$ and 1 hour) with observed organoleptically by 50 panelists. From the results of this research note to give soaking time organoleptic assessment on the color range $4.00-4.82$, aroma 4.34 - 5.12, the texture of 4.02 - 4.52, tenderness 5.20 - 5.36, flavor 3.98 - 4.58 . Based on the results of the assessment concluded that broiler meat is soaked for 1 hour in lemon cui organoleptic (color, aroma, texture, tenderness and flavor) can be accepted by consumers.

Key words : broiler meat, lemon cui, organoleptic properties 


\section{PENDAHULUAN}

Perkembangan yang pesat dari ayam pedaging (broiler) karena adanya sektor industri pendukung, seperti pabrik pakan, pembibitan, rumah potong, farmasi dan prosessing. Broiler dipanen pada umur 31 - 33 hari dengan berat rata-rata 1.67$2.10 \mathrm{~kg} / \mathrm{ekor}$, karena konsumen cenderung membeli karkas utuh yang tidak terlalu besar, selain itu dagingnya cukup lunak, lemaknya tidak terlalu banyak dan tulangnya tidak terlalu keras (Anjarsari, 2010).

Daging broiler merupakan pangan hewani yang bernilai gizi tinggi karena kaya akan protein, lemak, vitamin dan mineral serta zat lainnya yang sangat dibutuhkan oleh tubuh. Pada daging dan produk olahan daging, mutu daging ditentukan oleh komposisi gizi atau rasio antara daging non-lemak dengan lemak dan palatabilitasnya yang mencakup penampakan, tekstur (juiciness dan keempukan) serta citarasa, secara visual mutu daging dinilai dari warna dan marbling. Kualitas daging dipengaruhi oleh beberapa faktor, baik pada waktu hewan masih hidup maupun setelah dipotong. Kriteria yang dipakai sebagai pedoman untuk menentukan kualitas daging yang layak konsumsi adalah : Keempukan daging ditentukan oleh kandungan jaringan ikat, semakin tua usia hewan susunan jaringan ikat semakin banyak sehingga daging yang dihasilkan semakin liat. Jika ditekan dengan jari daging yang sehat akan memiliki konsistensi kenyal. Kandungan lemak (marbling) adalah lemak yang terdapat diantara serabut otot (intramuscular), lemak berfungsi sebagai pembungkus otot dan mempertahankan keutuhan daging pada waktu dipanaskan. Marbling berpengaruh terhadap citra rasa. Warna daging bervariasi tergantung dari jenis hewan secara genetik dan usia. Rasa dan aroma dipengaruhi oleh jenis pakan. Daging berkualitas baik mempunyai rasa gurih dan aroma yang sedap.

Daging broiler sering direndam dalam perasan lemon cui sebelum digoreng dan diolah dalam bentuk lainnya, dengan tujuan untuk menghilangkan rasa tengik, bau amis dan menambah citarasa dalam daging.Perendaman pada dasarnya proses meresapnya cairan ke dalam daging sampai batas keseimbangannya, lama proses perendaman tergantung jenis pelarut, bahan dasarnya dan jenis potongan.

Lemon cui (Citrus microcarpa) merupakan buah yang tidak asing di Indonesia dan sangat terkenal di Sulawesi Utara, lemon ini memiliki variasi penggunaan lebih banyak dibandingkan 
dengan lemon lain sehingga sering disebut sebagai buah serba guna. Lemon cui mempunyai aroma yang kuat dan citarasa khas serta memiliki sifat-sifat kimia yang berbeda dibandingkan dengan jenis lemon yang lain. Asam sitrat banyak terdapat dalam lemon cui dan merupakan agen yang mampu menciptakan citarasa asam dan aroma khas terhadap daging broiler.

Berdasarkan uraian diatas maka telah dilakukan penelitian yang bertujuan untuk mengetahui sejauh mana pengaruh penggunaan lemon cui terhadap sifat organoleptik daging broiler dengan lama perendaman yang berbeda.

\section{MATERI DAN METODE PENELITIAN}

Penelitian ini dilakukan sejak tanggal 7 sampai 14 April 2014 bertempat di Laboratorium Teknologi Hasil Ternak Fakultas Peternakan Universitas Sam Ratulangi Manado. Bahan yang digunakan dalam penelitian ini adalah broiler berumur 5 minggu yang diambil daging bagian dada sebanyak 1.000 gram dan 600 $\mathrm{ml}$ air perasan dari 60 butir buah lemon cui, untuk pengujian organoleptik disediakan air mineral dan mentimun.

Rancangan percobaan yang digunakan dalam penelitian ini adalah Rancangan Acak Lengkap (RAL) (Steel and Torrie, 1994) dengan 4 perlakuan dan sebagai ulangan adalah panelis sebanyak 50 orang. Menggunakan metode pengujian organolepik yang menggunakan skala hedonik. Sebagai perlakuan dalam penelitian ini adalah waktu perendaman daging dalam perasan lemon cui (Citrus microcarpa) yang disusun sebagai berikut

M1 = lama perendaman $4 \mathrm{Jam}$

M2 = lama perendaman $3 \mathrm{Jam}$

M3 = lama perendaman $2 \mathrm{Jam}$

M4 = lama perendaman $1 \mathrm{Jam}$

Data respon ditransformasi, hasil uji hedonik ditabulasi data respon dari skala hedonik ke numerik dan data yang diperoleh dianalisa dengan Analisis Keragaman (Analysis of Variance), untuk mengetahui perlakuan - perlakuan mana yang berbeda nyata secara statistik dilakukan pengujian dengan Uji Wilayah Berganda Duncan (Duncan Multiple Range Test) (Steel and Torrie, 1994).

\section{HASIL DAN PEMBAHASAN}

Uji organoleptik terhadap suatu bahan pangan merupakan indikator yang dapat menunjukkan tingkat penerimaan konsumen terhadap produk tersebut. Mutu organoleptik daging broiler yang direndam dengan menggunakan perasan lemon cui yang diamati dalam penelitian ini, meliputi warna, aroma, tekstur, keempukan dan citarasa. Hasil pengamatan pengaruh lama 
Tabel 1: Rataan pengaruh lama perendaman lemon cui terhadap sifat organoleptik daging broiler

\begin{tabular}{lllll}
\hline \multirow{5}{*}{ Variabel } & \multicolumn{4}{l}{ Perlakuan Lama Perendaman } \\
\cline { 2 - 5 } & M4 & M3 & M2 & M1 \\
& 1 jam & 2 jam & 3 jam & 4 jam \\
\hline Warna & $4.82^{\mathrm{a}}$ & $4.68^{\mathrm{ab}}$ & $4.18^{\mathrm{b}}$ & $4.00^{\mathrm{c}}$ \\
Aroma & $5.12^{\mathrm{a}}$ & $5.06^{\mathrm{ab}}$ & $5.00^{\mathrm{ab}}$ & $4.34^{\mathrm{c}}$ \\
Tekstur & $4.52^{\mathrm{a}}$ & $4.50^{\mathrm{a}}$ & $4.48^{\mathrm{a}}$ & $4.02^{\mathrm{a}}$ \\
Keempukan & $5.20^{\mathrm{a}}$ & $5.24^{\mathrm{a}}$ & $5.32^{\mathrm{a}}$ & $5.36^{\mathrm{a}}$ \\
Citarasa & $4.58^{\mathrm{a}}$ & $4.12^{\mathrm{b}}$ & $4.10^{\mathrm{cb}}$ & $3.98^{\mathrm{cb}}$
\end{tabular}

Keterangan : Superskrip berbeda pada baris yang sama artinya berbeda nyata $\quad(P<0.01)$

perendaman dalam perasan lemon cui terhadap mutu organoleptik daging broiler, selama penelitian disajikan pada Tabel 1 .

\section{Warna Daging}

Hasil pengamatan untuk pengaruh lama perendaman dalam perasan lemon cui terhadap warna daging, dapat dilihat pada Tabel 2. Data tersebut menunjukkan bahwa tingkat kesukaan panelis terhadap warna daging dengan lama perendaman yang berbeda, terdapat pada kisaran rataan 4.00 (netral) sampai 4.82 (agak menarik). Rataan skor tertinggi dari warna daging berada pada lama perendaman 1 jam yaitu 4.82 dan rataan skor terendah berada pada lama perendaman 4 jam yaitu 4.00 .

Hasil analisis sidik ragam menunjukkan bahwa perlakuan lama perendaman daging broiler dalam perasan lemon cui berpengaruh sangat nyata $(\mathrm{P}<0.01)$ terhadap warna daging.

Hasil uji lanjut dengan Uji Wilayah Berganda Duncan menunjukkan bahwa pada perlakuan lama perendaman 1 jam tidak memberikan pengaruh nyata $(\mathrm{P}>0.05)$ dengan 2 jam tetapi berpengaruh nyata terhadap 3 dan 4 jam. Perlakuan lama perendaman 2 jam tidak memberikan pengaruh nyata $(\mathrm{P}>0.05)$ dengan 3 jam, tetapi berpengaruh sangat nyata $(\mathrm{P}<0.01)$ terhadap 4 jam. Perlakuan lama perendaman 3 jam memberikan pengaruh sangat nyata $(\mathrm{P}<0.01)$ terhadap 4 jam. Perlakuan lama perendaman 4 jam berpengaruh sangat nyata $(\mathrm{P}<0.01)$ terhadap 1, 2 dan 3 jam. Hal ini disebabkan panelis lebih menyukai warna daging yang kemerah-merahan dari pada warna daging yang pucat. Semakin lama 
daging direndam dalam perasan lemon cui daging menyebabkan akan semakin pucat, sehingga terjadi penurunan tingkat kesukaan dari perlakuan 1 sampai 4 jam. Hal ini diduga karena makin lama perendaman daging makin banyak menyerap air lemon sehingga dapat mempengaruhi warna daging broiler. Mioglobin dapat dirusak oleh air lemon yang sifatnya asam karena banyak mengandung sitrat sehingga warna memudar selain itu zat karoten masuk ke dalam daging mempengaruhi warna daging. Hadiwiyoto (1992), menyatakan bahwa daging unggas mengandung zat warna (mioglobin) dan adanya gugus heme dengan satu molekul atom Fe yang mudah terdegradasi dan terhidrolisis sehingga warna daging berubah.

\section{Aroma Daging}

Hasil pengamatan untuk perendaman daging broiler dalam perasan lemon cui berpengaruh terhadap aroma daging, dapat dilihat pada Tabel 2. Rataan tingkat kesukaan panelis terhadap aroma daging berkisar antara 4.34 (netral) sampai 5.12 (agak suka). Rataan skor terendah berada pada perlakuan lama perendaman 4 jam yaitu 4.34 dan rataan skor tertinggi berada pada lama perendaman 1 jam yaitu 5.12 .

Hasil analisis sidik ragam menunjukkan bahwa perlakuan perendaman daging broiler dalam perasan lemon cui berpengaruh sangat nyata $(\mathrm{P}<0.01)$ terhadap aroma daging.

Hasil uji lanjut dengan menggunakan Uji Wilayah Berganda Duncan menunjukkan bahwa aroma daging pada perlakuan lama perendaman 1 jam tidak memberikan pengaruh nyata ( $>0.05)$ dengan 2 dan 3 jam, tetapi memberikan pengaruh sangat nyata $(\mathrm{P}<0.01)$ terhadap 4 jam. Perlakuan lama perendaman 2 jam tidak memberikan pengaruh nyata $(\mathrm{P}>0.05)$ dengan 3 jam tetapi memberikan pengaruh sangat nyata $(\mathrm{P}<0.01)$ terhadap 4 jam. Perlakuan lama perendaman 3 jam memberikan pengaruh sangat nyata $(\mathrm{P}<0.01)$ terhadap 4 jam. Perlakuan lama perendaman 4 jam memberikan pengaruh sangat nyata $(\mathrm{P}<0.01)$ terhadap 1, 2 dan 3 jam. Hal ini diduga disebabkan semakin lama daging direndam dalam perasan lemon cui maka semakin banyak yang meresap sehingga terjadi degradasi komponen bahan pangan yang mempengaruhi aroma daging. Selain itu aroma khas daging hilang. Hal ini sejalan dengan pendapat Tranggono (1991), bahwa degradasi asam lemak tak jenuh dengan perpanjangan rantai karbon menyebabkan perubahan aroma yang mencolok. Adanya variasi penilaian yang terlihat pada panelis, disebabkan oleh perbedaan kebiasaan makan dari panelis. Perbedaan pola serta kebiasaan makan 
pada kelompok-kelompok manusia menyebabkan tingkat kesukaan yang berbeda-beda pula (Maynard, 1965).

\section{Tekstur Daging}

Tekstur daging merupakan penampakan bagian luar daging untuk mengetahui kasar dan halusnya daging. Menilai Tekstur suatu bahan, adalah salah satu unsur kualitas bahan pangan yang dapat dirasa dengan rabaan ujung jari, lidah, mulut atau gigi.

Data hasil pengamatan untuk pengaruh perendaman daging broiler dalam perasan lemon cui terhadap tekstur daging, dapat dilihat pada Tabel 2 . Penilaian panelis terhadap tekstur daging berkisar antara 4.02 sampai 4.52 (netral). Sesuai dengan hasil analisis sidik ragam, dapat dikatakan bahwa perlakuan perendaman daging broiler dengan menggunakan perasan lemon cui tidak memberikan pengaruh nyata $(\mathrm{P}>0.05)$ terhadap tekstur daging. Tekstur daging broiler relatif sama, hal ini disebabkan dengan penambahan perasan lemon cui tidak mempengaruhi serabut daging, tekstur daging dipengaruhi oleh struktur myofibril (Shrimpton dan Miller, 1960).

Judge dkk.(1989), daging ayam mempunyai tekstur yang halus karena daging ayam mempunyai serabut otot yang kecil sehingga memiliki struktur miofibril yang kecil.

\section{Keempukan Daging}

Keempukan daging adalah parameter dalam menetukan kualitas daging yang diuji secara sensoris. Data hasil pengamatan untuk pengaruh lama perendaman daging broiler dalam perasan lemon cui terhadap keempukan daging, dapat dilihat pada Tabel 2. Rataan tingkat kesukaan panelis terhadap keempukan daging berkisar antara 5.20 sampai 5.36 (agak empuk). Sesuai dengan hasil analisis sidik ragam, dapat dikatakan bahwa perlakuan perendaman daging broiler dalam perasan lemon cui tidak memberikan pengaruh nyata $(\mathrm{P}>0.05)$ terhadap keempukan daging. Hal ini dapat dipengaruhi oleh jaringan ikat yang sedikit lebih empuk daripada otot yang mengandung jaringan ikat dalam jumlah yang besar. Selain itu tiga komponen utama daging yang andil terhadap keempukan atau kealotan yaitu jaringan ikat, serabut-serabut otot, dan jaringan adipose (Soeparno, 2009). Disamping itu daging yang empuk adalah hal yang paling dicari konsumen (Komariah dkk., 2004).

\section{Citarasa Daging}

Data hasil pengamatan untuk pengaruh lama perendaman dalam air perasan lemon cui terhadap citarasa daging, dapat dilihat pada Tabel 2. Hasil penelitian tersebut menunjukan bahwa 
rataan skor tingkat kesukaan panelis terhadap citarasa daging pada lama perendaman yang berbeda, berkisar antara 3.98 (netral) sampai 4.58 (agak enak), dengan rataan skor tertinggi berada pada perlakuan lama perendaman 1 jam yaitu 4.58 dan rataan skor terendah berada pada perlakuan lama perendaman 4 jam yaitu 3.98 .

Hasil analisis sidik ragam, menunjukkan bahwa perlakuan perendaman daging broiler dalam perasan lemon cui berpengaruh sangat nyata $(\mathrm{P}<0.01)$ terhadap citarasa daging. Hasil uji lanjut dengan Uji Wilayah Berganda Duncan menunjukkan bahwa perlakuan lama perendaman 1 jam memberikan pengaruh sangat nyata $(\mathrm{P}<0.01)$ dengan 2 , 3 dan 4 jam. Perlakuan 2 jam tidak memberikan pengaruh nyata $(\mathrm{P}>0.05)$ dengan 3 dan 4 jam. Perlakuan lama perendaman 3 jam tidak memberikan pengaruh nyata $(\mathrm{P}>0.05)$ terhadap 4 jam. Perlakuan lama perendaman 4 jam memberikan pengaruh sangat nyata $(\mathrm{P}<0.01)$ dengan 1 jam tetapi tidak memberikan pengaruh nyata $(\mathrm{P}>0.05)$ terhadap 2 dan 3 jam. Dapat disimpulkan bahwa tingkat kesukaan terhadap citarasa daging broiler menurun dengan semakin lama perendaman. Hal ini diduga karena semakin lama perendaman dapat terjadi reaksi kimia pada daging broiler diantaranya pemutusan rantai asam lemak sehingga mempengaruhi tingkat kesukaan terhadap citarasa. Hadiwiyoto (1992), menyatakan bahwa perubahan citarasa dapat disebabkan oleh adanya degradasi atau peruraian senyawa makromolekul daging broiler. Diantaranya degradasi asam lemak rantai karbon pendek menjadi lebih panjang yang dapat menyebabkan citarasa berubah dan intensitasnya menurun (Tranggono, 1991).Selain itudalam air lemon terdapat zat-zat yang dapat mempengaruhi citarasa diantaranya adalah asam dan gula (Winarno dkk. 1980).

\section{KESIMPULAN}

Berdasarkan hasil analisa data dan pembahasan untuk semua variabel dalam penelitian ini dapat disimpulkan bahwa perendaman daging broiler dalam perasan lemon cui selama 1 jam secara organoleptik untuk warna, aroma, tekstur, keempukan dan citarasa masih dapat diterima oleh konsumen.

\section{DAFTAR PUSTAKA}

Ali, K. M, S. J. Rondonuwu, L. Pangemanan, A. Waworuntu. 1993. Kajian Awal Beberapa Komponen Biologi dan Kimia Lemon Cui (Citrus Mitis). Laporan Penelitian Proyek Peningkatan Perguruan Tinggi. Universitas Sam Ratulangi, Manado. 
Anjarsari, B. 2010. Pangan Hewani Fisiologi Pasca Mortem dan Teknologi. Graha Ilmu. Yogyakarta.

Anonim. 2010. Citrus Microcarpa. Http//buahku.wordpress.com/2013/ 08/17/tanaman-lemon.html. (Diakses pada tanggal 18 Februari 2014, 12:02:53 AM WITA).

Aunan, W. J. and C. E. Kolari. 1965. Meat and Meat Products, Encyclopedia of Chemical Technology. Ed. By Kirk. Othmer. John Wiley Sons, Inc. New York. pp. $167-184$.

Davey, C. L., Kutiel, H. and Gilbert, K. V. 1967. Food Science. J.Fd. Technol. 2, 53.

De Man, J. M. 1997. Kimia Pangan. Edisi Kedua. Penerbit ITB. Bandung.

Hadiwiyoto, S. 1992. Kimiadan Teknologi Daging Unggas. Pusat Antar Universitas Pangan dan Gizi. UGM, Yogyakarta.

Judge, M. D., E. D. Aberle, J. C. Forrest, H. B. Hedrick, and R. A. Merkel. 1989. Principles of Meat Science. 2nd. ed. Kendall Hunt Publishing Company, Derbuque, Lowa.

Komariah, I. I. Arief dan Y. Wiguna. 2004. Kualitas Fisik dan Mikrobia Daging Sapi Yang Ditambah Jahe (Zinger Officinaleroecoe) Pada Konsentrasi dan Lama Penyimpanan Yang Berbeda. Media Peternakan Vol. 28(2) : 38 87.
Larmond, E. 1970. Methods of Sensory Efaluation of Food. Canada Departement of Agriculture. Ottawa.

Lawless, H. T. and Heyman, H. 1998. Sensory Evaluation of Food. Chapman \& Hall. New York.

Maynard, A. A. 1965. Principles of Sensory Evaluation of Food. Academic press New York. London.

Mirah, A. Dp. 1981. Pengaruh Penyuntikan Papain Pada Pengempukan Daging Ayam Secara Antemortem. Tesis. Fakultas Peternakan. UNSRAT, Manado.

Morton, J. 1987. Calamondin. p. 176-178. In: Fruits of Warm Climates. Miami, Florida.

Mountney, G. J. and C. R. Parkhurst. 1995. Poultry Products Technology. 3rd. Food Produck Press Bighamton NY.

Naruki, S. 1991. Gizi Terapan. Pusat Antar Universitas Pangan dan Gizi. UGM, Yogyakarta.

Plantamor. 2012. Informasi Spesies. http://www.plantamor.com. (Diakses pada tanggal 02 April 2014).

Shrimpton, D. H., and W. S. Miller. 1960. Some Couses of Toughness In Broilers. II. Effects Of Breed, Management, And Sex. Br. Poult. Sci. 1:111 - 120 . 
Soekarto, S. T. 1985. Penilaian Organoleptik. Pusat Pengembangan Teknologi Pangan. Institut Pertanian Bogor. Press Bogor.

Soekarto T. S. dan N. Hubeis, 1992. Petunjuk Menggunakan Laboratorium Metode Penelitian Indrawi. Pusat Antar Universitas Pangan dan Gizi. IPB. Bogor.

Soeparno, 2009. Ilmu dan Teknologi Daging. Perpustakaan IAIN Syekh Nurjati Cirebon. UGM-Press. Yogyakarta.

Steel, R. G. D. dan J. H. Torrie. 1994. Prinsip dan Prosedur Statistika, Suatu Pendekatan Biometrik. Ahlih bahasa B. Sumantri. PT Gramedia Pustaka Utama. Jakarta.

Tranggono. 1991. Citarasa (Flavor) Bahan Makanan. Pusat Antar Universitas Pangan dan Gizi. UGM, Yogyakarta.

Winarno, F. G., S. Fardiaz dan D. Fardiaz. 1980. Pengantar Teknologi Pangan. Gramedia. Jakarta.

Winarno, F. G. dan B. S. Laksmi. 1974. Dasar Pengawetan, Sanitasi dan Keracunan. Departemen Teknologi Hasil Pertanian. Fatemeta IPB, Bogor.

Winarno, F. G. 1997. Kimia Pangan dan Gizi. PT Gramedia Pustaka Utama, Jakarta. 